\title{
The Structural Features of Code-Switches in the Modern British Novels
}

\author{
By Lyudmila Gunko*
}

\begin{abstract}
The author examines the structural features of code-switches in two novels "The Corsican Caper" and "Chasing Sezanne" written by the modern British writer Peter Mayle. The matrix language of multilingual utterances is English and the embedded language is French. Code-switches are the alternate use of units of one language within the utterance in another language during one conversation. Two groups of code-switches are distinguished: those in the bilingual characters' speech and those in the author's speech. Peter Mayle has used different types of code-switches to emphasize their bilingual competence when they switch from English to French in various communicative situations. Different types of code-switches have been fixed: intersententional, intrasententional - within a phrase (insertions, embedded language islands), clause-switches, and tag-switches. The author of the article has found out 434 units of code-switches in the two novels, with 258 units being represented in the author's speech and 176 units in the bilingual characters' speech. The study has shown that the most frequently used type in the bilingual characters' speech and in the author's speech is intrasententional within a simple sentence, with embedded language islands being predominant.
\end{abstract}

Keywords: code-switches, bilingualism in fiction, bilingual speech, matrix language, embedded language

\section{Introduction}

Code-switching (CS) results from language contact along with borrowing, pidginization, convergence, and language shift. It occurs in a bilingual or multilingual context in which, cause, of their linguistic background, people communicate by means more than one language or dialect (Ahmed 2016, p. 207). CS may occur among immigrant communities, regional minorities, and native multilingual groups. Gumperz and Hernandez wrote that it could be found "each time minority language groups come into contact with majority language groups under conditions of rapid social change" (Gumperz and Hernandez 1969, p. 2, Gardner-Chloros 2009, p. 20).

Müller affirms that code-switches in literature, as in life, have always been a result of language contact, mostly due either to individual biographical experiences of the author, to the contact between minority languages and the majority. Besides, the process of migration which has increased remarkably in the age of globalization also helps the increase of the language contacts (Müller 2015, p. 249).

In contrast to the great amount of attention paid to spoken code-switches,

\footnotetext{
"Postgraduate Student, Cherepovets State University, Russia.
} 
literary CS has only recently become a subject of such interest. The first conference which was devoted to this topic was organized at Birkbeck, University of London on 5 July 2013 and called "Code-switching in Literature". As it has been noted by Jonsson (2010) and Sebba et al. (2012), linguists have paid far less attention to written CS than to conversational ones (Gardner-Chloros and Weston 2015, p. 183). Callahan also mentions that code-switches are less seen in prose. Nevertheless, she underlines that CS are often used in dialogue and in forms meant to represent the stream of consciousness style utterances in writing (Callahan 2004, p. 11). The importance of studying literary code-switches is enhanced by the rise of bilingual literature and a Pulitzer-winning 'Spanglish' novel may signal that the use of CS in literature is quite an important legitimized topic (Montes-Alcalá 2015, p. 269).

This study seeks to survey the structural features of literary code-switches employed in the modern British novels - "The Corsican Caper" and - "Chasing Cezanne" written by Peter Mayle.

Previous researchers have demonstrated that code-switches are often used in literature "in a humorous or satirical way, represent the speech of foreigners, for example, they are used in Shakespeare, Henry V; Charlotte Brontë, Jane Eyre; Tolstoy, War \& Peace." The usage of CS can give the impression of an informal register, of a rejection of literary standards, in general, to highlight the orality of text (Gardner-Chloros and Weston 2015, p. 186).

In traditional studies of bilingualism, it is generally acknowledged that languages are separate entities and the ability to keep them apart is the criterion of bilingual skills. On the contrary, the negative notion to CS was not always present, as in earlier times the ability to switch languages correctly was recognized as an aspect of the writer's skill and knowledge. Therefore, literary CS may perform indexing and mimetic functions in the literary texts (Weston and Gardner-Chloros 2015, p. 195).

In the same way, as spoken CS shows a glimpse of how bilinguals use their linguistic resources, so the deployment of CS in literature may clarify hidden structures and intentions which are less apparent in a monolingual text (GardnerChloros and Weston 2015, p. 189).

Hess observes that in bilingual literature, languages are not switched just because of the author's bilingualism but rather to fulfill artistic and literary functions (Hess 1996, p. 6).

Gardner-Chloros considers CS as the use of several languages or varieties within the same text and argues that this phenomenon introduces a lot of possible functions within multilingual literature. For example, the writer may employ different languages for presenting different characters or voices, to distinguish various parts of the text, or to characterize the community. Likewise switching between the grammatical unit such as sentence or word may be used for creating comic effect (Gardner-Chloros 2015 and Weston, p. 186).

In her study, Montes-Alcalá determines that CS in the novels is used for a variety of socio-pragmatic and stylistic purposes which are similar to ones in bilingual speech. Moreover, that CS serves for characterization and as a tool for the description of the bicultural environment (Montes-Alcala 2015, p. 276). 


\section{Theoretical Background}

Bloomfield (1933) famously stated that bilingualism comes from the speaker's ability to control the use of two languages. Thus, a bilingual is considered to be the person who can easily control the produce of languages. Bloomfield believed that switches are supposed to be an indicator of the lack of proficiency. Hence, Weinreich (1953) defined bilingualism as the practice of alternately using two languages. Vogt in his article (1954) is inspired by the notion of Weinreich, but he already assumes that all languages and languages users experience language contact and the process of code-switching is natural and is an important element of language change. Later, Haugen (1969) has mentioned that bilingualism starts at the moment when a speaker of one language can produce complete substantial utterances in the other language. In the last years, language alteration is considered not as a deficit to be stigmatized, but as an additional resource through which social and rhetorical meanings are expressed (Milroy and Muysken 1995, p. 9).

Over time, the definition of bilingualism has been adopted and changed by many researchers, among them Grosjean, who defined it as the use of two or more languages or dialects in everyday life (Grosjean and Byers-Heinlein 2018, p. 5). Depending on the interlocuter bilinguals communicate differently. They avoid using their second language when they talk with monolinguals or they may adopt it in interaction with bilinguals by switching over completely to another language or by adding some elements of another language into the language of communication (Grosjean 2012, p. 10).

The use of code-switches was often stigmatized, luckily, recent researches have changed their approach. In the latest studies, many of them stated that different neural networks produce different languages in the brain of a bilingual person. That also results in different access in speech production. García supposes that the work of linguists is to identify all cases of interference as the result of language contact. She remarks that code-switches can be defined as shifting from language belonging to one grammatical system to another (García and Wei 2014, p. 12).

When the person communicates with someone bilingual who speaks the same languages, it is evident that they may bring in the base language of conversation some words of another language. It is possible to happen if the speakers feel comfortable in the communication and if there is a need to switch. In this case, the speakers make a shift to the other language and then revert to their first language. After years of research on such CS aspects as sociolinguistic, psycholinguistic, grammatical, it became clear that it was not a haphazard behavior but a wellcontrolled process for conveying linguistic and social information. There are a lot of reasons to change language, for example, using the more precise word or expressing, filling a linguistic need, marking group identity, excluding or including someone, raising one's status (Grosjean 2012, pp. 18-19).

CS had attracted the most attention of researchers interested in bilingualism after the work of Gumperz and his associates in the early 1970s (Blom and Gumperz 1972). In the literature, many different definitions have been proposed to explain the notion of CS: in a general way, Gumperz defines CS as the 
juxtaposition within the same speech exchange of speech passages belonging to two different grammatical systems or sub-systems (Gumperz 1982a, p. 59). Mostly, he focuses on the discourse and interactional functions that CS perform for speakers. Gumperz is interested in the influence of some situational factors such as topic, participants, and settings (Gumperz 1982a, 1982b). Poplack determines code-switch as the alternation of two languages within a single discourse, sentence, or constituent (Poplack 1980, p. 583). Grosjean adds that CS may include a word, a phrase, one sentence as well as several sentences (Grosjean 1982, p. 146). So, he suggests the following definition - "the alternate use of two or more languages in the same utterance or conversation." (1982, p. 145). Heller characterizes it in the following way - "the use of more than one language in the course of a single communicative episode" (Heller 1988, p. 1). Auer writes that it is the alternating use of more than one language (Auer 1984, p. 1). Similarly, Milroy and Muysken describe the phenomenon of CS as the alternative use by bilinguals of two or more languages in the same conversation (Milroy and Muysken 1995, p. 7).

We will use the definition of Myers-Scotton which is adopted for analyzing code-switched utterances. She describes CS as the use of two or more languages in the same conversation, usually within the same conversational turn, or even within the same sentence of that turn. She notices that CS may take place on any level of linguistic differentiation such as languages, style, or dialect, register (MyersScotton 1993, p. 8).

In her works Myers-Scotton raises three important questions: 1) when bilingual speakers switch, how free is alternation from the structural point of view; 2) Are there any structural constraints for code-switches? 3) And finally, is there a connection between the structural types of code-switches and the social functions they perform? (Myers-Scotton 1997, p. 1).

The use of code-switches allows speakers to increase their flexibility of expression. It differs their style of speaking of monolinguals' one. Thus, switching helps to underline the nuances of social relationships with help of the sociopsychological connection of the languages engaged.

The Matrix Language Framework originally developed by Myers-Scotton is used in this study. According to this model, there is one language in the bilingual phrase which gives the morphosyntactic frame for the sentence. This language establishes the order of morphemes in the sentence. Mostly, it means that the frame of the sentence is supposed to specify the morpheme order. The other language is embedded language which is limited by the Matrix language (MyersScotton 1997, p. 10). In our research the Matrix language of utterances is English and the embedded language is French.

In general, the Matrix Language-Frame (MLF) model analyzes CS in terms of two interacting hierarchies. Firstly, the two languages that participate in creating CS play different roles. It means that there are the Matrix Language (ML) and Embedded Language (EL) distinctions; secondly, the content and system morphemes distinction. The ML constrains the role of another language or languages. The content and system morphemes distinction permit the prediction of the distribution of ML and EL morphemes (Myers-Scotton and Jake 2001, p. 89). 
It is clear that CS is not done haphazardly, but may be structured (Bakuuro 2020, p. 217).

According to the structure, code-switches are classified into two main groups. Firstly, there are intersententional and intrasententional code-switches. Intersentential code-switches are formed when the language is switched within the sentence boundaries at the beginning or at the end of a sentence. The intrasententional code-switches may be divided into several sub-types: clauseswitches, parenthetical switches, also there are insertions and island switches. Insertions are built with the help of a single content morpheme. The EL islands consist of two or more EL content morphemes or combine content morphemes with the system morphemes (Chirsheva and Korovushkin 2020, p. 1502).

As reported by Poplack, tag switches are grammatically detachable in a sentence and may be inserted almost anywhere in the sentence without fear of violating any grammatical rule, that is why this kind of switch is used more frequently than others. She makes a conclusion that the fluent bilinguals often switch within the sentence i.e. they use intrasententional type of CS, while speakers with lower bilingual proficiency prefer intersententional type or tag switches. Supposedly, it is related to the fact that intra-sentential switches pose the greatest grammatical and syntactical risks to one's fluency (Poplack 1980, p. 589).

\section{Materials and Methods}

The purpose of the paper is to describe structural aspects of code-switches employed in two English novels -"The Corsican Caper" and -"Chasing Cezanne".

The data for this study are 225 units extracted from the modern novel - "The Corsican Caper" written by Peter Mayle in 2014 and 209 units extracted from the novel - "Chasing Cezanne" written in 1998. The analysis of the code-switches consists of the following steps:

1) The searching of code-switches in the novel.

2) Distinguishing CS in the author's speech and in the dialogues presented in the text of the novel.

3) Classifying code-switches into intersententional and intrasententional.

4) Describing the structure of intersententional code-switches.

5) Classifying intrasententional code-switches into clause-switches, parenthetical switches, islands, and insertions.

6) Analyzing the data of code-switches represented in the book according to its structure.

In this paper, code-switches will be analyzed with the help of the MLF model.

\section{Peter Mayle and his Characters}

Peter Mayle is a British writer who became famous owning to his series of 
books dedicated to Provence. His book -"A Year in Provence" was released in the United States in 1990 and was named a bestseller and gained an award for being named Best Travel Book of the Year. Since then, his books have been translated into many languages and stayed one of his best-known books along with the novel "A Good Year". The French government made Peter Mayle a Chevalier de la Légion d'honneur (Knight of the Legion of Honor) in 2002. The novel "The Corsican Caper" is a part of the collection that is dedicated to the adventures of one character - Sam Levitt.

Sam Levitt is American, after graduating from a law college, he entered the world of corporate law. He was not interested in the idea of a violent crime, he liked the use of intelligence as a criminal weapon; Sam was fascinated by the ingenious crimes without any blood. So, he decided to work on the legitimate side as an investigator and consult on criminal matters. At the beginning of his career, he traveled a lot visiting South America, Africa and Russia. Eventually, his appreciation of wine brought him to France where he spent some time and picked up some French (Mayle 2009, p. 25).

In the novel, Sam and Elena go to France to help their friend Francis Reboul. We may suggest that Sam's bilingualism is non-balanced because he acquired French when he was already an adult during his trip to France after graduating from college. Sam also comments that his French is not good enough as he would like it to be (Mayle 2009, p. 90).

It is interesting to read Elena's remark about the change in Sam's behavior and manner of speaking when Sam comes to another country and speaks French. She thinks that he enjoys life much more than usual in such moments. For example: "Over the years, Elena had become used to Sam having "bon viveur" moments as soon as he set foot in France. It was part of the travel experience" (Mayle 2014, p. 18) and one more example: "Elena smiled. Sam's enthusiasm, when he was having one of his "bon viveur" moments, was infectious" (Mayle 2014, p. 45).

Peter Mayle wrote the novel - "Chasing Cezanne" in 1998. The action of the novel - "Chasing Cezanne" takes place in Cap Ferrat. The main character is Andre Kelly who lives in New Your, but comes to France to work on a series of photographs of the rich house for a well-known magazine. Andre happened to notice how a Cézanne is loaded into a plumber's truck near the house of its owner. The valuable painting is taken away and the photographer is drawn into a real investigation that threatens to kill him. The main characters of the novel are bilinguals, and thus speak English and sometimes switch to French in different situations.

\section{First Case Study: Analysis of "The Corsican Caper"}

Peter Mayle uses code-switches in the dialogues of his characters and the author's speech. As a consequence, two groups of CS are distinguished: CS presented in the characters' speech and in the author's speech i.e., the text without any dialogues. 
Firstly, we will analyze code-switches in the characters' speech presented in the novel "The Corsican Caper".

A) Intersententional code-switches make 16 units:

"In his brief but charming remarks, Reboul thanked his audience for their support and emphasized that that evening was just a start - the first step on a journey that he hoped would end with a spectacular addition to the delights of his beloved Marseille. - "But I'm sure you're all hungry," he said, looking toward the summer kitchen, -and I can see my friend Alphonse the chef tapping his watch. In my experience, he is not a man to be kept waiting. "Allons, mes amis! À la bouffe!" (Mayle 2014, p. 31).

Francis Reboul hosted a dinner, after giving his speech, he invited everyone to start celebrating. The audience is multilingual, so the main part of the speech was in English, however, Reboul being French, shows his hospitality by switching to French at the end of his discourse. Reboul switches in order to mark closeness, to emphasize bonds, and to welcome everyone. Code-switch "Allons, mes amis!" occurs after the speaker has completed the sentence in English and started his next sentence with EL. The phrase "Â la bouffe!" is used between two other sentences within a statement of the same character. Both intersententional code-switches are marked with exclamations and they impel interlocutors to take action.

B) The next structural type of CS is intrasententional. In this case, the switch occurs within the same sentence.

Parenthetical switches:

"He seemed to have shrunk behind the wheel, his face the picture of apprehension. Olivier opened the driver's door and, in his most threatening police manner, told Rocca to get out. -"Nobody ever comes down here," he said, -so we can have a nice quiet chat without being disturbed. "Bon", now let me see your driver's license, and give me your cell phone" (Mayle 2014, p. 52).

Olivier talks to his American friends in English, however, he switches to his native language sometimes, for example, when he is emotional. Here, Olivier uses interjection which function is mimetic. It helps to more faithfully represent the voice of someone and to underline his nationality along with his portrait. French code-switch "bon" is isolated inside the simple sentence and marked by a comma.

Tag-switches:

-"Let me see what I can find out. Rich Russians in Europe aren't too difficult to track. I'll try to have something for you in a couple of days. Meanwhile, don't do anything I wouldn't do, "d'accord"?" (Mayle 2014, p. 24).

Hervé talks to Reboul, he switches to French in order to emphasize the importance of his message; he doesn't want Reboul to act without his permission of police officer. Code-switch - "d'accord?" is used at the end of the sentence in 
order to impel others to agree with the statement and to mark the importance of the question.

Intrasententional CS presented by the form of address:

"Well, "mon vieux", said Hervé, -"what have you done now? Too many parking tickets? Assaulted a politician? Been caught pinching girls' bottoms again?" As his laughter came down the phone, Reboul could picture Hervé's face-round, smiling, and cheerful, a misleading face that concealed the tough and determined officer Reboul knew him to be" (Mayle 2014, p. 24).

Hervé uses phatic greeting in Reboul's native language in order to make a contact and to mark closeness between them. There is a form of address "mon vieux" inside the sentence that is connected with the ML part of the sentence.

Insertions make 37 units:

"I think you will enjoy the cheeses. There are three: one soft and creamy; one hard and strong; and one "cendré", with a fine dusting of ashes. The combination is subtle and delicious" (Mayle 2014, p. 109).

In the presented example, Alphonse is the classic French chef, he enumerates the dishes that he prepared for today. When he talks about the types of cheeses, he uses a specific word "cendré". This term is used in French because it can express more nuances of meaning, and there is no suitable equivalent in English. Some French words denote the object of French reality, thus they can be used to fill gaps since they invoke different associations and connotations than their English counterparts. Code-switch "cendré" is an insertion because it is built with the help of a single EL content morpheme - adjective and without any EL system morphemes.

Island switches make 39 units:

"Sam was impressed. -Have you done this sort of thing before?" - "Oh, once or twice. Before working for Monsieur Francis, I was a cop. In fact," he said, putting a finger to his lips, - "I've still got my gun. But that's strictly "entre nous." (Mayle 2014, p. 51).

In the given example, Olivier shares his little secret with Sam and uses French to highlight that it should not be told to anyone else. Olivier with the help of CS emphasizes the closeness between them. We assume the French phrase - "entre nous" is an island switch because it consists of two morphemes.

Secondly, we will analyze code-switches in the author's speech:

A) Intersententional CS have not been observed in this group.

B) Intrasententional code-switches:

Parenthetical switches: 
"They were all, without exception, "affaires à saisir", to be snapped up before July and August, when the hot money came down from Paris and people would be fighting -literally fighting- over such highly desirable properties" (Mayle 2014, p. 44).

As we can see, in this sentence the characters discuss the available properties, the author uses the common expression "affaires à saisir" which means "amazing bargain". The purpose of CS is to attract the reader's attention, to add emphasis to the particular concept. The French expression - "affaires à saisir" is inserted into the English sentence and is marked by commas.

Clause switches:

"He embraced Reboul, kissed Elena's hand, shook Sam's, and led them up the beach toward a low, open-fronted shack with tables and chairs arranged under faded canvas umbrellas. A sign hanging above the bar read Le Cac Quarante and, in smaller letters, "Les chèques sont pas acceptés"' (Mayle 2014, p. 22).

In this paragraph, Peter Mayle describes the situation and the place, which the characters visit. He switches to French in order to give additional information. Besides, the French name of the bar and the inscription help to include readers into the environment of France and its language. The CS - "les chèques sont pas acceptés" is a part of the complex sentence and isolated inside another English sentence.

Tag-switches:

"Six months previously, Reboul had allowed his good nature to get the better of him and had agreed to act as host for a dinner in aid of a local charity, Les Amis de Marseille. The charity had been sponsored by a committee of local businessmen, whose aim was not entirely without self-interest; charity, after all, begins at home. But the cause was worthy and locally very appealing: to Promote" (Mayle 2014, p. 28).

So, Reboul hosts the dinner for the charity, which name is given in French for the purpose of depicting the original title. By doing this, the bilingual writer achieves a higher degree of accuracy in describing the place and environment where the action takes place. Code-switch - "Les Amis de Marseille" is joined to the main clause by the means of comma and brings extra information to the English sentence.

Insertions are presented by 30 units:

"There were also new museums and exhibition sites, newly created gardens both wet and dry, even a glamorous glass ombrière to give visitors to the fish market some shelter from the elements, if not from the ripe language" (Mayle 2014, p. 17). 
The author of the novel gives the description of Marseille, of its museums, gardens, and fish markets. The underlined word is the specific term of French life and its realities, that's why it is presented in original form. It can help the readers to learn a new term and to dive into the atmosphere of the city. The word "ombrière" is an insertion because it consists of one EL content morpheme - noun.

Island switches make 67 units:

"The langoustes were fresh, firm, and sweet, served with a mayonnaise almost thick enough to need a knife, made with egg yolks and extra-virgin Corsican olive" (Mayle 2014, p. 23).

In this example, the focus of attention is on the term "langoustes" which defines the local food. The well-known dish is associated with France and codeswitch allows readers to connect with the country and the characters. The EL island - "langoustes" is inserted into the ML morphosyntactic frame with the help of the plural ending - s. Quantitative analysis of the data is represented in Table 1.

Table 1. Types of Code-Switches Employed in the Novel "The Corsican Caper"

\begin{tabular}{|l|c|c|c|}
\hline Types of CS & Author's speech & Characters' speech & Total \\
\hline & 119 & 106 & 225 \\
\hline $\begin{array}{l}\text { Intersententional } \\
\begin{array}{l}\text { Intrasententional } \\
\text { within clause-switches and tag- } \\
\text { switches }\end{array}\end{array}$ & - & 15 & 16 \\
\hline Insertions & 32 & 15 & 37 \\
\hline Island switches & 67 & 37 & 67 \\
\hline
\end{tabular}

From Table 1, a total of 225 units are presented mostly by intrasententional type of CS in both groups: author's and characters' speech with island switches being predominant.

\section{Second Case Study: Analysis of "Chasing Cezanne"}

Now, we will analyze code-switches in the characters' speech presented in the novel - "Chasing Cézanne".

A) Intersententional code-switches make 31 units:

"The chauffeur dealt with the bags. Andre dealt with the chauffeur. Camilla's incredulous voice echoed down the hall. - But that's impossible. "C'est impossible". Are you sure there isn't anything" Other staff was summoned and interrogated. The hotel played hunt the message" (Mayle 1998, p. 28).

We can see the reiteration of the phrase, frequently a message in one code is repeated in the other code, in this case, to show the emotional condition of the 
speaker. Camilla is upset because her luggage was lost, she repeats the words in French for emphasizing her disappointment. It is stated by Gumperz (1982a, p. 78) and confirmed by Jonsson (2010, p. 1301) that reiteration should not be viewed as mere "translations" from one language to another, but rather as an alteration of the expression in another language. In this particular case, CS has a specific function of reiteration which allows to demonstrate the emotional state of the person. So, French code-switch - "C'est impossible" occurs between two English sentences within a statement of the same speaker.

B) The next structural type of CS is intrasententional.

Tag-switches:

"Paradou smiled. -A hundred thousand, "d'accord"?" He prepared to leave, feeling that the day hadn't been entirely wasted. -I'll be in touch." (Mayle 1998, p. 174).

Similarly, as in one of the previous examples, CS "d'accord?" is used here at the end of the sentence in order to impel others to agree with the statement and to mark the importance of the question.

Intrasententional CS presented by the form of address:

"Franzen busied himself with a bottle of rose, filling everyone's glass while he spoke: -Everything is good here, but the pissaladière is exceptional, and you won't find better lamb in Provence. Am I right, "chérie"? He spoke to her in the solicitous tone of a man who was still on slightly shaky ground and treading carefully" (Mayle 1998, p. 188).

Franzen switches to French as a means of showing affection for his wife. The form of address inside the English sentence - "chérie?" is connected with the ML part of the sentence.

Insertions make 9 units:

"Paradou shook his head in exasperation. I can't see through stone walls. Wait, they've come out again. Just the three of them" Silence while he watched them walk up the street. -"OK. They're going into a "café. I'll call you later." Paradou saw that the café was crowded. Service would be slow. He licked his lips at the sight of a waiter with a tray of cold golden beers and walked down the street in search of a car to rent" (Mayle 1998, p. 184).

Paradou uses the original French term. Code-switch "café" is an insertion because it is built with the help of a single EL content morpheme - noun, without any EL system morphemes.

Island switches are presented by 14 units: 
"An involuntary shudder. -How about "ris de veau"?"

-"Delicious, but I don't think you want to hear about it."

-"That bad?"

-"That bad." (Mayle 1998, p. 139).

The speaker depicts such a cultural concept as food by switching to the language of its origin. The French phrase -"ris de veau" is an island switch because it consists of two content morphemes - nouns and a system morpheme preposition "de". Secondly, we will analyze code-switches in the author's speech of the novel "Chasing Cézanne".

A) Intersententional code-switches make 4 units:

"The woman turned to look at him, her face a study in scorn. With exaggerated deliberation, she took out a pair of dark glasses, put them on, and eased away from the curb. "Bon". Paradou parked, cut the engine, and spread a copy of Soldier of Fortune, the magazine of the well-read mercenary, across the steering wheel. Not having more than a few words of English, and those mostly the scrapings of the language picked up in bars, he missed the subtleties of the editorial content" (Mayle 1998, p. 155).

The author uses the interjection for deepening the description of the events. The reader should not forget that the action takes place in France, that the characters are bilinguals, and some of them are even French. Besides, Peter Mayle demonstrates the inner thoughts of the bilingual writer and bilingual characters for whom it is natural to switch languages. Code-switch - "bon" occurs between two author's sentences with the ML grammar.

B) The next structural type of CS is intrasententional.

Parenthetical switches make 12 units:

"Lucy stopped at one of the stalls and made her first Parisian purchase: two tiny roses of the darkest red, boutonnières, which she put in the lapels of the men's jackets" (Mayle 1998, p. 158).

The French word - "boutonnières" is a specific French term. It is inserted into the English sentence and is marked by commas.

Insertions make 54 units:

"He picked up his "kir", and condensation from the base of the glass dripped onto the Mediterranean just south of Nice." (Mayle 1998, p. 33).

In the given example, the author describes the environment of the restaurant and Andre's behavior, he uses the original term for the French drink - "kir". The word - "kir" is an insertion because it consists of a content morpheme - a noun, without any system morphemes. 
Island switches make 69 units:

"Andre drove slowly up toward Saint-Jeannet, comparing the views on either side of the road. To his right, "jolies villas" huddled together as far as the eye could see, a jumble of concrete and tile that covered the terraced land and extended all the way down to the Mediterranean" (Mayle 1998, p. 25).

The example given above is the EL Island because it is inserted into the ML morphosyntactic frame with the help of two content morphemes: the combination of an adjective and a noun in the plural forms. CS is a way to evoke richer images describing the place, an attempt at a more faithful representation of the country and its landscapes. Table 2 represents the statistics in the survey.

Table 2. Types of Code-Switches Employed in the Novel "Chasing Cezanne"

\begin{tabular}{|l|c|c|c|}
\hline Types of CS & Author's speech & Characters' speech & Total \\
\hline & 139 & 70 & 209 \\
\hline Intersententional & 4 & 31 & 35 \\
\hline $\begin{array}{l}\text { Intrasententional } \\
\text { within clause-switches and tag- } \\
\text { switches }\end{array}$ & 12 & 16 & 28 \\
\hline Insertions & 54 & 9 & 63 \\
\hline Island switches & 69 & 14 & 83 \\
\hline
\end{tabular}

It is clear that a total of 209 units are presented mostly by intrasententional type of CS in both groups: author's speech and characters' speech.

\section{Conclusion}

The study focuses on the structural features of code-switches in two novels written by Peter Mayle, where the matrix language is English, and the embedded language is French. The Matrix Language Framework is used in this study. Two groups of code-switches have been distinguished: those in the bilingual characters' speech and those in the author's speech. Based on the results, it can be concluded that there are 434 units of code-switches in the two novels, with 258 units being represented in the author's speech and 176 units in the bilingual characters' speech.

There are 225 units of code-switches that have been found in the novel "The Corsican Caper", with 119 units being represented in the author's speech and 106 units in the bilingual characters' speech. In this novel intrasententional codeswitches presented in the author's speech make 97 units (island switches - 67, insertions - 30), intrasententional within clause-switches and tag-switches make 22 units. The overall amount of intrasententional code-switches in the characters' speech is 76 (island switches - 39, insertions - 37), intrasententional within clauseswitches and tag-switches make 15 units and intersententional CS make also 15 units in our data. We can observe the general dominance of intrasententional type over others. 
Intersententional code-switches are typical for the character's speech because with their help the heroes impel interlocutors to take actions, they may demonstrate emotional condition and send a strong message. Intersententional code-switches show the speaker's ability to build sentences in both languages and use them alongside which is especially relevant in depicting Sam's bilingualism.

Intersententional CS, intrasententional CS presented by the form of address and tag-switches are well-suited for representing the speech of characters in writing because they are more similar to the way the real people communicate in bilingual speech. Intrasententional type prevails in both characters' speech and author's speech because it allows to use different structures of code-switches in the author's narration and in the dialogues, while intersententional CS mostly emphasize the orality of the literary text.

There are 209 units of code-switches that have been found in the novel "Chasing Sezanne", with 139 units being represented in the author's speech and 70 units in the bilingual characters' speech.

In our study intrasententional code-switches presented in the author's speech make 123 units (island switches - 69, insertions - 54), intrasententional within clause-switches and tag-switches make 12 units, intersententional CS make 4 units.

The overall amount of intrasententional code-switches in the characters' speech is 23 (island switches - 14, insertions - 9), intrasententional within clauseswitches and tag-switches make 16 units and intersententional CS make 31 units in our data. We can observe a slight dominance of intrasententional type over intersententional.

The study has shown that the most frequently used type in the bilingual characters' speech and in the author's speech is intrasententional within a simple sentence, with embedded language islands being predominant.

Intrasententional type is dominant because the author switches from English to French to convey French realities such as names of streets or special dishes which are most noticeable when the writer switches within the simple sentence: "Anse des Pêcheurs, La Vallée des Grenouilles, baguette, bouillabaisse rouille, foie gras, calanques, myrte".

The EL islands prevail because with their help it is possible to show different structural variations of CS: a combination of two nouns, a noun in a plural form, a noun with an article, a noun with an adjective.

Intrasententional code-switches may be used for inserting French idioms, for a quotation. Intrasententional CS is the most popular structural type in the characters' speech because it may be used for greeting, addressing, and it may convey emotions.

Peter Mayle uses different structures of code-switches in the characters' speech in order to underline the bilingual competence of his characters. They switch from English to French in different situations, for example, for conveying their emotions, greetings, apologizing, discussing realities. To sum up, in the characters' speech CS is used to show the emotional condition of the character, as a means of showing affection to one another in the form of address, to give the additional information to the message of the speaker, to emphasize the closeness 
between people, to underline the nationality, to denote the specific French term, for example, food.

Moreover, the author also wants to point out the character's ability to grammatically correctly build sentences in both languages, taking into account the place of code-switches. They insert correctly French words or phrases into the Matrix language depending on the communicative mean and their abilities.

The use of CS in the author's speech probably means that the writer tries to integrate readers into the French environment and to bring them closer to his characters, by using code-switches when describing the French world surrounding his heroes. In the author's speech, code-switches may help to name the cultural concept, to include readers into the environment of the country, to emphasize the additional information, to differ characters.

\section{References}

Ahmed M (2016) Arabic codes in Hebrew texts: on the typology of literary code-switching. Journal of Jewish Languages 4(2): 203-230.

Auer P (1984) Bilingual conversation. Amsterdam: John Benjamins.

Bakuuro J (2020) Dagaare-English code switching: an analytical survey. Athens Journal of Philology 7(3): 215-234.

Blom JP, Gumperz JJ (1972). Social meaning in linguistic structure: Code-switching in Norway. In JJ Gumperz, D Hymes (eds.), Directions in Sociolinguistics, 407-434. New York: Holt, Rinehart and Winston, Inc.

Bloomfield L (1933) Language. New York: Henry Holt.

Callahan L (2004) Spanish/English Codeswitching in a Written Corpus. Amsterdam and Philadelphia: John Benjamins.

Chirsheva G, Korovushkin P (2020) Structural characteristics of code switching in fouryear old bilinguals. In The European Proceedings of Social and Behavioural Sciences: 1494-1504.

García O, Wei Li (2014) Translanguaging: language, bilingualism and education. UK: Palgrave Macmillan.

Gardner-Chloros P (2009) Code-switching. Cambridge: Cambridge University Press.

Gardner-Chloros P, Weston P (2015) Code-switching and multilingualism in literature. Language and Literature 24(3): 182-193.

Grosjean F (1982) Life with two languages: An introduction to bilingualism. Cambridge: Harvard University Press.

Grosjean F, Li P (2012) The psycholinguistics of bilingualism. Hoboken, NJ: John Wiley $\&$ Sons.

Grosjean F, Byers-Heinlein K (2018) The listening bilingual: Speech perception, comprehension, and bilingualism. Hoboken, NJ: John Wiley \& Sons.

Gumperz J (1982a) Conversational code-switching. In JJ Gumperz (ed.), Discourse Strategies, 55-99. Cambridge: Cambridge University Press.

Gumperz J (1982b) Language and social identity. In Studies in Interactional Sociolinguistics. Cambridge: Cambridge University Press.

Gumperz J \& Hernandez E (1969) Cognitive aspects of bilingual communication. Working Paper No.28, Language behavior research laboratory. Berkeley: University of California Press.

Haugen E (1969) The Norwegian language in America: a study in bilingual behavior. 
Indiana University Press.

Heller M (1988) Codeswitching: anthropological and sociolinguistic perspectives. Berlin: Mouton de Gruyter.

Hess N (1996) Code switching and style shifting as markers of liminality in literature. Language and Literature 5(1): 5-18.

Jonsson C (2010) Functions of code-switching in bilingual theater: an analysis of three Chicano plays. Journal of Pragmatics 42(5): 1296-1310.

Mayle P (1998) Chasing Cezanne. New York Vintage books. A division of Random House, Inc.

Mayle P (2009) The Vintage Caper. New York: Alfred A. Knopf.

Mayle P (2014) The Corsican Caper. New York: Alfred A. Knopf.

Milroy L, Muysken P (1995) Introduction: code-switching and bilingualism research. In L Milroy, P Muysken (eds.), One Speaker, Two Languages: Cross-Disciplinary Perspectives on Code-Switching, 1-14. Cambridge: Cambridge University Press.

Montes-Alcalá C (2015) Code-switching in US Latino literature: the role of biculturalism. Language and Literature 24(3): 264-281.

Müller KB (2015) Code-switching in Italo-Brazilian literature from Rio Grande do Sul and São Paulo: a sociolinguistic analysis of the forms and functions of literary codeswitching. Language and Literature 24(3): 249-263.

Myers-Scotton C (1993) Duelling languages: grammatical structure in codeswitching. Oxford: Clarendon Press.

Myers-Scotton C (1997) Duelling languages: grammatical structure in codeswitching. Oxford: Clarendon Press.

Myers-Scotton C, Jake JL (2001) Explaining aspects of code-switching and their implications: one mind, two languages: bilingual language processing. Oxford: Blackwell.

Poplack S (1980) Sometimes I_ll start a sentence in Spanish y terminal Espanol: towards a typology of code-switching. Linguistics 18 (7/8): 581-618.

Sebba M, Mahootian SH, Jonsson C (2012) Language mixing and code-switching in writing: approaches to mixed-language written discourse. New York: Routledge.

Vogt H (1954) Language contacts. Word 10(2-3): 365-374.

Weinreich U (1953) Languages in contact: findings and problems. New York: Linguistic Circle of New York.

Weston P, Gardner-Chloros P (2015) Mind the gap: what codeswitching in literature can teach us about code-switching. Language and Literature 24(3): 194-212. 